Chogoria Hospital for identifying patients. We thank Eunice Muthoni for conducting the interviews in Kenya and Allison Worth and Judith Brown for reviewing data analysis in Scotland and Kenya, respectively. We thank Kirsty Boyd and Derek Doyle for commenting on drafts of this paper and Arthur Andere, James Mwenda, and Jane Njeru, members of the advisory group which provided support in Kenya.

Contributors: See bmj.com

Funding: These studies were funded in Scotland by a grant from the Chief Scientist Office of the Scottish Executive, and in Kenya by a donation from an Edinburgh patient to Edinburgh University.

Competing interests: None declared.

1 Singer PA, Bowman KW. Quality care at the end of life. BMJ 2002;324:1291-2.

2 Ramsay S. Raising the profile of palliative care for Africa. Lancet 2001;358:734.

3 Olweny C. Ethics of palliative care medicine: palliative care for the rich nations only! J Palliat Care 1994;10:17-22.

4 De Boer CN, McNeil M. Hopsital outreach community-based health care: the case of Chogoria, Kenya. Soc Sci Med 1989;28:1007-17.

5 Isichei E. A history of Christianity in Africa. London: SPCK, 1995.
6 Mbiti JS. African religions and philosophy. London: Heinemann, 1969

7 Green J, Britten N. Qualitative research and evidence based medicine. BMJ 1998;316:1230-3.

8 Murray SA, Boyd K, Kendall M, Worth A, Benton T.F. Dying of lung cancer or cardiac failure: prospective qualitative interview study of patients and their carers in the community. BMJ 2002;325:929-2.

9 Grant E, Murray SA, Grant A, Brown J. A good death in rural Kenya? Listening to Meru patients and their families talk about care needs at the end of life.J Palliat Care (in press).

10 Murray JL, Lopez AD. The global burden of disease. Boston: Harvard School of Public Health, 1996.

11 Lincoln YS, Guba EG. Paradigmatic controversies, contradictions and emerging confluences. In: Denzin N, Lincoln YS, eds. Handbook of qualitative research. London: Sage 2000;163-188.

12 World Health Organization. Handbook for representing results of cancer treatment. Geneva: WHO, 1979

13 Defilippi K. Palliative Care issues in sub-Saharan Africa. Int J Palliat Nurs 2000;6:108

14 Westphal VB. Monograph on six home care programmes in Uganda and Zambia. Geneva: WHO, 1990.

15 Olweny C. Cultural issues in sub-Saharan Africa. In: Doyle D, Hanks G, McDonald N, eds. Oxford textbook of palliative medicine. Oxford: Oxford University Press, 1996.

16 World Health Organization. Macroeconomics and health: investing in health for economic development. Report of the commission on macroeconomics and health. Geneva: WHO, 2001.

(Accepted 23 December 2002)

\title{
Association between practice size and quality of care of patients with ischaemic heart disease: cross sectional study
}

\author{
Azeem Majeed, Jeremy Gray, Gareth Ambler, Kevin Carroll, Andrew B Bindman
}

Proportionally fewer inpatients die in hospitals that do more operations than in hospitals that do fewer. ${ }^{1}$ Similar associations between outcome and the size of hospitals have been found in other studies. An association between size and outcome may also be important in primary care settings, where most patients with chronic illnesses are managed. If large practices or those that treat more people provide better care, this could have important implications for the organisation of primary care services. We looked for an association in patients with ischaemic heart disease because the management of this disease is an international priority. ${ }^{2}$

\section{Participants, methods, and results}

From September 2000 to May 2001, we identified patients diagnosed as having ischaemic heart disease using paper and computerised medical records in four primary care groups in southwest London (69 general practices; population 382 188). Seven general practices did not take part.

We recorded patients as hypertensive if their blood pressure was more than 140/85 $\mathrm{mm} \mathrm{Hg}$. We classed cholesterol concentrations greater than $5 \mathrm{mmol} / \mathrm{l}$ as high and defined patients with a body mass index (weight $(\mathrm{kg}) /$ height $\left(\mathrm{m}^{2}\right)$ ) of 30 or greater as obese. We extracted information on treatment with cardiovascular drugs from computerised records. Fifteen practices were unable to supply some data and were excluded from some of the analyses.

We calculated the proportion of patients in each practice whose risk factors were assessed or controlled; who were taking aspirin, statins, $\beta$ blockers, or angiotensin converting enzyme inhibitors; or who had had revascularisation treatment. To examine the association of practice size and volume of cases with quality of care, we used a logistic population averaged generalised estimating equation model, adjusted for age and sex, that allowed for clustering within practices.

Practice size varied from 1265 to 13147 patients (mean 5762). In total, 6888 people had ischaemic heart disease; the number of cases in individual practices varied from 12 to 326 (mean 111) and prevalence varied from $0.45 \%$ to $4.37 \%$ (mean $1.96 \%$ ).

Only records of cholesterol concentrations showed an improvement with increasing number of cases of ischaemic heart disease. An increase of 10 in the number of cases was associated with a $6 \%$ increase in the odds of recording (table). On average, a practice with 200 patients with ischaemic heart disease would have recorded cholesterol concentrations for $69 \%$ of patients registered with the practice compared with $56 \%$ in a practice with 100 cases.

\section{Comment}

Most aspects of the management of ischaemic heart disease in primary care were not associated with the number of cases managed. We also found no association between practice size and the quality of care. This suggests that the trend in the NHS towards larger general practices by itself has little impact on the quality of chronic disease management in primary care.

Although recent developments in the NHS have cast doubt on the future of smaller practices, both patients and the doctors seem happy with smaller practices. Smaller practices are seen as more accessible and achieve higher levels of patient satisfaction. ${ }^{45}$ The NHS should reconsider how it can improve the quality of care provided by general practices, without relying on the presumed benefits of consolidating them into
Primary Care Research Unit, School of Public Policy, University College London, London WC1H 9QU Azeem Majeed professor of primary care

Battersea Research Group, Bolingbroke Hospital, London SW11 6HN

Jeremy Gray director

Kevin Carroll specialist registrar in public health medicine

Medical Statistics Unit, Research and Development

Directorate,

University College London Hospitals NHS Trust, London NW1 2LT

Gareth Ambler statistician

Departments of Medicine,

Epidemiology, and

Biostatistics,

University of

California San

Francisco, San

Francisco, CA

94118, USA

Andrew B Bindman professor of medicine, epidemiology, and biostatistics

Correspondence to: A Majeed a.majeed@ucl.ac.uk

BMJ 2003;326:371-2 
Univariate associations between number of cases (adjusted for practice size) and practice size and management of ischaemic heart disease in 62 general practices, southwest London, September 2000 to May 2001

\begin{tabular}{|c|c|c|c|c|}
\hline \multirow[b]{2}{*}{ Variable } & \multicolumn{2}{|l|}{ No of cases } & \multicolumn{2}{|l|}{ Practice size } \\
\hline & Odds ratio $(95 \% \mathrm{CI})^{*}$ & $\begin{array}{c}P \\
\text { value }\end{array}$ & Odds ratio $(95 \% \mathrm{Cl})^{*}$ & $\begin{array}{c}P \\
\text { value }\end{array}$ \\
\hline Blood pressure recorded & 1.01 (0.97 to 1.06$)$ & 0.58 & $1.04(0.95$ to 1.14$)$ & 0.36 \\
\hline Blood pressure optimal & 1.01 (1.00 to 1.02$)$ & 0.18 & 0.99 (0.96 to 1.02$)$ & 0.63 \\
\hline Cholesterol recorded & $1.06(1.03$ to 1.10$)$ & 0.001 & 1.05 (0.98 to 1.13$)$ & 0.18 \\
\hline Cholesterol optimal & 1.01 (1.00 to 1.03$)$ & 0.06 & 1.02 (0.99 to 1.05$)$ & 0.21 \\
\hline Body mass index recorded $†$ & 1.07 (0.96 to 1.19$)$ & 0.22 & $1.04(0.95$ to 1.14$)$ & 0.36 \\
\hline Body mass index optimal $\dagger$ & 0.99 (0.98 to 1.01) & 0.45 & 0.99 (0.97 to 1.02$)$ & 0.51 \\
\hline Prescribed statin & $1.00(0.99$ to 1.01$)$ & 0.85 & 1.03 (1.00 to 1.05$)$ & 0.08 \\
\hline Prescribed aspirin & $0.99(0.97$ to 1.01$)$ & 0.17 & 1.01 (0.97 to 1.05$)$ & 0.53 \\
\hline Prescribed $\beta$ blocker $\dagger$ & 0.96 (0.90 to 1.03$)$ & 0.23 & $1.06(0.96$ to 1.16$)$ & 0.28 \\
\hline $\begin{array}{l}\text { Prescribed angiotensin converting } \\
\text { enzyme inhibitor† }\end{array}$ & 0.93 (0.87 to 0.99$)$ & 0.02 & 1.05 (0.96 to 1.16$)$ & 0.27 \\
\hline Revascularisation $\dagger$ & 0.98 (0.96 to 1.01$)$ & 0.14 & 1.02 (0.97 to 1.06$)$ & 0.49 \\
\hline
\end{tabular}

*0dds ratios are adjusted for age and sex, and are per 10 patients for number of cases and per 1000 patients for practice size.

$\dagger 15$ practices could not supply data and were excluded.

larger units. Other initiatives-for example, the use of disease facilitators, local incentive schemes, expansion in specialist services, and the development of general practitioners with special interests-need to be evaluated to see if they can achieve this objective.
We thank Rumana Omar for advice on the analysis of clustered data.

Contributors: All the authors planned the study. GA did the statistical analysis. AM wrote the paper and received comments from the other authors. AM and JG are guarantors.

Funding: The data collection for this study was funded by Battersea; Balham, Tooting, and Wandsworth; East Merton and Furzedown; and Putney and Roehampton primary care groups. An additional grant was received from Merton Sutton and Wandsworth Health Authority. The Battersea Research Group is a primary care research network funded by the Department of Health. AM holds a primary care scientist award, funded by the NHS Research \& Development Directorate.

Competing interests: None declared.

1 Luft HS, Bunker JP, Enthoven AC. Should operations be regionalized? The empirical relation between surgical volume and mortality. $N$ Engl J Med 1979;301:1364-9.

2 EUROASPIRE I and II group. Clinical reality of coronary prevention guidelines: a comparison of EUROASPIRE I and II in nine countries. Lancet 2001;357:995-1001.

3 Gray J, Majeed A, Kerry S, Rowlands G. Using computerised medical records to identify patients with ischaemic heart disease in general practice. $B M J$ 2000;321:548-50.

4 Campbell SM, Hann M, Hacker J, Burns C, Oliver D, Thapar A, et al. Identifying predictors of high quality care in English general practice: observational study. BMJ 2001;323:784-7.

5 Baker R. Characteristics of practices, general practitioners and patients related to levels of patients' satisfaction with consultations. Br J Gen Pract $1996 ; 45: 654-9$.

(Accepted 5 September 2002)

\section{My most unfortunate mistake}

\section{Courtesy towards NHS staff is a must}

I had just started as a new medical house officer in an eminent teaching hospital on the south coast of England, having recently completed my surgical job. Like all new doctors, I spent the first few days finding my way around the wards and getting to know the routine. I was booming with enthusiasm and confidence and was somewhat arrogant. The job certainly was not easy. A typical day consisted of an endless ward round, and during on-calls we would be lucky to have a few minutes to ourselves. On a typical post-take ward round we saw more than 20 new admissions, and, with an on-call commitment of one in four, we were always on the go.

I was initially taken aback by the enormity of the workload in a new environment, and my initiation was not made easier by being on call on the first day as well as the first weekend. Junior doctors can react to such situations in many ways. My response was to be uncharacteristically arrogant, patronising, and even occasionally rude, and, as a new face in the hospital, I made a lot enemies very fast. I was surprised by how quickly most of the staff, including nurses and medical staff, realised that I was a potential troublemaker and someone who needed to be watched. This led to a flood of informal complaints to my consultant, so that, within days of my starting, he summoned me and told me that I was the worst house officer he had ever had. The combination of workload and friction with other staff reached such a level that, by the end of my second week, having worked non-stop for 10 days and done four on-calls, I was considering resigning. I was exhausted, frightened, and very bitter, feeling that I had been treated as a scapegoat.

After a relaxing weekend, however, I pulled my strength and my wits together and, after some thought, realised how wrong I had been. The words of my senior house officer kept echoing in my mind. He had warned me about how important it was to establish good rapport with the other staff and thereby get them on my side. I turned up to work on time on the following Monday and managed to partially redeem myself within a few weeks. Unfortunately, the damage had been done and, as first impressions last, even with all my good intentions I could not totally clear my name.

The most important lesson I learnt is the fundamental importance of dealing diplomatically with colleagues. Working in the NHS is demanding and highly stressful for everyone, and, by being polite and courteous, even if others are treating you differently, you can make a lot of difference. You then will realise that you become more efficient, as you can flourish in a pleasant multidisciplinary environment where all can function, attain their full potential, and best serve the patients' interests.

And here is something for senior NHS staff who have to deal with new house officers every six months. Please realise how much pressure they are under at the start of their careers; their arrogance and even discourtesy may just be part of their coping mechanism. It may be better if you gently habituate them into their new role instead of reacting defensively and ripping them apart.

Cyrus Abbasian

We welcome articles up to 600 words on topics such as A memorable patient, A paper that changed my practice, $M y$ most unfortunate mistake, or any other piece conveying instruction, pathos, or humour. If possible the article should be supplied on a disk. Permission is needed from the patient or a relative if an identifiable patient is referred to. We also welcome contributions for "Endpieces," consisting of quotations of up to 80 words (but most are considerably shorter) from any source, ancient or modern, which have appealed to the reader. 